\title{
STRATIGRAFI SEJARAH DESA SAKO KECAMATAN RAMBUTAN KABUPATEN BANYUASIN SEBAGAI SUMBER PEMBELAJARAN SEJARAH
}

\author{
Oleh: Herman Wijaya* \\ *Program Studi Pendidikan Sejarah, FKIP Universitas PGRI Palembang
}

\begin{abstract}
ABSTRAK
Keberadaan jejak pantai purba di desa Sako Kecamatan Rambutan Kabupaten Banyuasin dapat dijadikan sumber pembelajaran sejarah, pembelajaran sejarah dengan memanfaatkan sumber sejarah lokal dapat memperkaya wawasan kesejarahan siswa di SMP Karya Sembawa. Permasalahan penelitian: Bagaimana Stratigrafi pantai kuno di desa Sako yang dapat dijadikan sebagai sumber pembelajaran sejarah siswa kelas VII SMP Karya Sembawa Kecamatan Sembawa Kabupaten Banyuasin"? Tujuan penelitian untuk mengetahui: a) stratigrafi sejarah pantai kuno desa Sako; b) nilai sejarah pada stratigrafi pantai kuno di desa Sako yang dapat dijadikan sebagai sumber pembelajaran sejarah. Metode penelitian yang digunakan deskriptif kualitatif dengan analisis data interaktif. Hasil penelitian: 1) Stratigrafi di desa Sako menggambarkan proses sejarah geologi; 2) Stratigrafi desa Sako menggambarkan nilai sejarah masa prasejarah dan masa klasik Hindu-Budha; 3) Stratigrafi desa Sako dapat dijadikan jadikan sumber pembelajaran sejarah Di SMP pada KI-3. Kompetensi Dasar 1.1 Mendiskripsikan keragaman bentuk muka bumi, proses pembentukan dan dampak nya terhadap kehidupan.
\end{abstract}

Kata Kunci: Stratigrafi Sejarah, Nilai Sejarah, desa Sako kecamatan Rambutan.

\section{A. PENDAHULUAN}

Pendidikan adalah pembelajaran pengetahuan, keterampilan, dan kebiasaan sekelompok orang yang diturunkan dari suatu generasi ke generasi berikutnya melalui pengajaran, pelatihan, atau penelitian. Pendidikan sering terjadi dibawah bimbingan orang lain, tetapi juga memungkinkan secara otodidak. Setiap pengalaman yang miliki efek formatif pada cara orang berfikir, merasa atau tindakan dapat dianggap pendidikan. Pendidikan umumnya dibagi menjadi tahap seperti persekolah, sekolah dasar, sekolah menengah dan kemudian perguruan tinggi, universitas atau magang.

Salah satu bidang ilmu yang merupakan cabang dari pendidikan ialah sejarah. Sejarah berasal dari bahasa Yunani "Historia" yang berarti penyelidikan, pengetahuan yang diperoleh melalui penelitian. Sejarah adalah studi tentang masa lalu, khususnya bagaimana kaitannya dengan peradaban hidup manusia. Dalam bahasa Indonesia sejarah babad, hikayat, riwayat atau tambo dapat diartikan sebagai kejadian dan peristiwa yang benar-benar terjadi dimasa lampau atau asal usul (keturunan) silsilah. Sejarah berhubungan dengan peristiwa masa lalu serta penemuan, koleksi, organisasi dan penjajian informasi yang mengenai peristiwa-peristiwa istilah ini mencangkup kosmik geologi, dan sejarah makhluk hidup. Peristiwa yang terjadi sebelum catatan tertulis disebut prasejarah.

Pengertian lokal tidak berbelit-belit seperti daerah regional. Istilah lokal mempunyai arti suatu tempat atau ruang sehingga sejarah lokal menyangkut lokalitas tertentu yang disepakati oleh para penulis sejarah, atau sejarawan dengan alasanalasan ilmiah, misalnya suatu ruang tempat tinggal suku bangsa ruang itu bisa lintas kecamatan, kabupaten, atau provinsi. Ruang itu dapat dalam bentuk suatu kota. Kota merupakan perkembangan dari suatu atau beberapa desa. Ruang desa adalah ruang yang bersifat asli sebagai bentukan masyarakat yang sangat khas. Ruang 
sejarah lokal merupakan lingkup geogerafis yang dapat dibatasi sendiri oleh sejarawan dengan alasan yang dapat diterima semua orang.

Menurut Mazhab Leicester menyatakan sejarah lokal adalah asal-usul, pertumbuhan, kemunduran, dan kejatuhan dari kelompok masyarakat lokal. Sejarah lokal merupakan serangkaian peristiwa yang benar-benar terjadi di suatu wilayah atau daerah tertentu yang memiliki nilai kelokalan tersendiri. Sejarah lokal memiliki ruang lingkup tertentu sehingga dapat dikatakan bahwa sejarah lokal adalah sejarah yang mempelajari khususnya suatu wilayah tertentu (Priyadi, 2012:6-7).

Menurut Septiana (2008:9). Nilai yaitu suatu makna yang terkandung di dalam sebuah benda baik tulisan ataupun lisan serta bentuk lain seperti bangunan nilai biasanya selalu diukur dengan sebuah angka, namun tidak semua nilai bisa dihitung dengan angka sebab ada nilai yang bersifat relative misalnya nilai keindahan. Suatu sejarah baik berbentuk bangunan ataupun berbentuk peristiwa memiliki nilainya masing-masing. Nilai bangunan sejarah misalnya dipandang memiliki makna sebagai simbol tentang adanya peristiwaperistiwa sejarah ditempat tersebut atau bersifat nyata. Sedangkan nilai dalam peristiwa sejarah lebih cendrung bersifat menyangkut dengan perasaan.

Konsep nilai sejarah menurut Atmosudiro dalam Humanika (2008:9-10). Menyatakan nilai sejarah (Historic Value) sebagai nilai kesejahteraan yang dimiliki suatu objek atau peristiwa-peristiwa yang penting melibatkan objek tersebut. Nilai sejarah tersebut dapat diketahui baik dari sumber tertulis, seperti prasasti dan karya sastra maupun sumber tak tertulis, seperti prasasti dan karya sastra maupun sumber tak tertulis misalnya gaya bangunan, seni arca, dan unsur-unsur bangunan lain.

Berdasarkan atas pengertian pendidikan dan sejarah diatas maka penulis berusaha untuk menemukan bagaimana pengaruh sebuah situs sejarah lokal terhadap pendidikan sejarah itu sendiri pada siswa kelas VII SMP Karya Sembawa Kabupaten Banyuasin. Untuk memecahkan masalah tersebut penulis melakukan penelitian terhadap sebuah situs kuno yang berada di desa tersebut yaitu sebuah situs pantai kuno yang ditemukan di lokasi kedukan yang terletak di desa Sako Kecamatan Kabupaten Banyuasin.

\section{B. METODE PENELITIAN Tempat Penelitian}

Penelitian ini dilakasanakan di dua tempat yaitu: (1) desa Sako Kecamatan Rambutan, pada lokasi penelitian ini dilakukan penelitian tentang letak stratigrafi pantai kuno dan (2) SMP Karya Sembawa Kecamatan Sembawa Kabupaten Banyuasin. Pada lokasi kedua penulis melakukan penelitian tentang pembelajaran sejarah stratigrafi pantai kuno kepada siswa kelas VII (tujuh) SMP Karya Sembawa Kabupaten Banyuasin.

\section{Waktu Penelitian}

Penelitian ini dilaksanakan kurang lebih menghabiskan waktu selama dua bulan yaitu pada bulan Maret-Mei 2016. Penelitian pertama yaitu penggalian lokasi stratigrafi dilaksanakan pada awal bulan Maret sedangkan penelitian kedua yaitu pelaksanaan pembelajaran sejarah tentang stratigrafi pantai kuno di kelas VII SMP Karya Sembawa dilaksanakan pada 2016.

\section{Metode dan Prosedur Penelitian}

Dalam penulisan skripsi ini penulis menggunakan metode penelitian Deskriptif Kualitatif, mengumpulkan sumber-sumber secara sistematis dan menggunakan sumber data secara mendalam.

\section{Data dan Sumber Data}

Ditinjau dari sumber datanya, maka tipe penelitian ini adalah penelitian lapangan (field reseach). Sebab data yang diperlukan dalam penelitian ini berasal dari lapangan 
khususnya dijadikan objek penelitian. Pendekatan yang digunakan dalam penelitian ini adalah pendekataan kualitatif, pendekatan adalah mendeskripsikan atau cerita yang dapat menggambarkan dari permasalah yang di teliti atau melakukan kajian ulang, bertanya kepada orang lain, menghimpun informasi yang sejenis untuk mempeoleh kesimpulan yang sama. Interpertasi terhadap isi dibuat dan disusun secara sistematik/menyeluruh dan sistematis.

Jenis data dalam penelitian ini adalah kualitatif yaitu data yang diungkapkan dalam bentuk kalimat serta uraian-uraian, bahkan dapat berupa cerita pendek (Bungin dalam Yanuarti 2013:263).

Dalam penelitian ini sumber data yang digunakan adalah sebagai berikut:

1. Dokumentasi

Data diperoleh melalui penelusuran dokumen/informasi dari desa Sako kecamatan Rambutan kabupaten Banyuasin.

2. Observasi

Kegiatan observasi tempat penelitian dilakukan di dua tempat berbeda, yaitu: lokasi kedukan desa Sako kecamatan Rambutan (lokasi ditemukannya situs pantai kuno) dan SMP Karya Sembawa (lokasi penelitian pembelajaran sejarah pantai kuno).

3. Wawancara

Pada kegiatan ini informasi diperoleh secara langsung dengan mengajukan beberapa pertanyaan kepada beberapa warga desa Sako, guru mata pelajaran IPS dan siswa kelas VII SMP Karya Sembawa.

\section{Teknik dan Prosedur Pengumpulan Data}

Teknik pengumpulan data merupakan langka yang paling utama dalam penelitian, karena tujuan utama dari penelitian adalah mendapatkan data, tanpa mengetahui teknik pengumpulan data, maka peneliti tidak mendaapatkan data yang memenuhi standar data yang ditetapkan (Sugiono dalam Yanuarti, 2013:262).

Dalam hal ini peneliti mengumpulkan data dengan teknik traingulasi. Teknik traingulasi diartikan sebagai teknik pengumpulan data yang bersifat mengambungkan dari berbagai teknik pengumpulan data dan sumber data yang telah ada. Teknik triagulasi ini dilakukan guna untuk mengumpulkan data sekaligus menguji kratibilitas data, yaitu mengecek kratibilitas atau keabsaham data dengan berbagai teknik pengumpulan data dan berbagai sumber.

Menurut Sugiono dalam Yuniarti (2013:264), ada dua jenis teknik triagulasi yaitu:

1) Triagulasi sumber berarti peneliti dalam mengumpulkan data dari sumber yang berbeda-beda dengan teknik yang sama.

2) Triagulasi teknik berarti peneliti mengumpulka data dengan menggunakan teknik yang berbeda-beda dengan sumber yang sama.

Dalam penelitian ini teknik pengumpulan data yang digunakan adalah triagulasi teknik untuk mengetahui penerapan pendekatan (cooperative learning) pada proses pembelajaran penelitian dalam mengumpulkan data dengan teknik wawancara, dukumentasi dan observasi dengan sumber yang sama.

a) Dokumentasi

Dokumentasi adalah cara
mengumpulkan data melalui peninggalan tertulis seperti arsip-arsip dan termasuk juga buku-buku pendapat, teori, dalil dan hukum dan lain-lain yang berhubungan dengan masalah penelitian (Margono dalam Yanuarti, 2013:265).

b) Wawancara

Wawancara digunakan sebagai tenik pengumpulan data apabila peneliti ingin melakukan sendiri pendahuluan untuk menemukan permasalahan yang harus diteliti, tetapi juga apabila peneliti ingin mengetahui hal- hal dari 
respon yang mendalam. (Sugiono dalam Yanuarti, 2013:266). Disini peran informal merupakan kunci penting dalam keberhasilan peneliti.

c) Observasi

Observasi adalah melakukan pengamatan dan pencatatan secara sistematis terhadap fenomenafenomena yang tampak pada objek penelitian (Nawawi dalam Yanuarti, 2013:266). Teknik ini digunakan untuk mengamati langsung keadaan Desa Sako dan pembelajaran sejarah di SMP Karya Sembawa.

\section{Analisis Data}

Menurut Sugiyono dalam Yanuarti (2013:267), analisis data kualitatif adalah proses mencari dan menyusun secara sistematis data yang diperoleh dari hasil dokumentasi, wawancara, kuisioner, dan observasi, catatan lapangan dengan cara mengorganisasikan data, ke sintesis menyusun ke dalam pola, memilih mana yang penting dan mana yang akan dipelajari, dan membuat kesimpulan sehingga mudah dipahami oleh diri sendiri maupun orang lain.

Sehubungan dengan teori diatas maka analisis yang digunakan dalam penelitian ini adalah deskriptif kualitatif dimana data informasi diperoleh dari lapangan dideskripsikan secara kualitatif. Adapun tahap-tahap yang dilakukan dalam analisis data adalah sesuai dengan yang dikemukakan, yaitu:

1) Pengorganisasian data dilakukan setelah data yang diperoleh dari setiap pertanyaan penelitiaan yang sudah dianggap memadai

2) Merumuskan dan menafsirkan data tentang penelitian

3) Mengambil kesimpulan akhir terhadap data-data dalam bentuk temuantemuan umum dan temuan khusus.

Menurut Miles dan Huberman (dalam Sugiyono, 2009:246-253) terdapat tiga jalur analisis data kualitatif, yaitu reduksi data, penyajian data dan menarik kesimpulan proses ini berlangsung terus menerus selama penelitian berlangsung, bahakan sebelum data benar-benar terkumpul, yaitu pertama, reduksi data merupakan analisis yang menajamkan, menggolongkan, mengarahkan, membuang yang tidak perlu dan mengorganisasikan data sedemikian rupa sehingga kesimpulan akhir dapat diambil. Kedua, penyajian data adalah kegiatan ketika sekumpulan informasi disusun, sehingga memberikan kemungkinan akan adanya penarikan kesimpulan. Bentuk penyajian data kualitatif berupa teks naratif berbentuk catatan lapangan. Ketiga, penarikan kesimpulan merupakan hasil analisis yang dapat digunakan untuk mengambil tindakan.

\section{HASIL DAN PEMBAHASAN}

Setelah kerajaan Majapahit runtuh yang ditaklukan oleh kerajaan Mataram yang terjadi abad 16, banyak pembesarpembesar kerajaan Majapahit tersebut beserta anak keturunannya mengungsi keplosok-kepelosok tanah air dan salah satunya tempat pengungsian pembesar Majapahit tersebut bekas kerajaan Sriwijaya yang juga sebelumnya merupakan daerah kekuasaan kerajaan Majapahit, pada saat itu kesultanan Palembang yang pertama yaitu diperintah oleh Sultan Ahmad Najamudi I, Adi Kusumah memerintah pada tahun (1758 M-1761 $\mathrm{M})$, pengungsi pembesar Majapahit tersebut sudah berada di bumi Palembang.

Mereka menyusuri sungai Musi diantaranya nenek moyang Sako yaitu Raden Fatahilah (Lazim disebut Raden Ariodila), dari sekian lama perjalanan menyusuri sungai Musi akhirnya mereka menghulu kearah Selatan memasuki anak sungai Musi yaitu sungai Komering (sekarang batang harian sungai dua), dan mereka pun memasuki anak sungai Komering yaitu sungai Parung sungai perbatasan marga Parung Priyayi dan OKI, menghilir kearah Timur dan di ujung sungai 
Parung inilah nenek moyang Sako bertempat tinggal Raden Fatahilah (7 bersaudara). Disanalah mereka membuka lahan ladang untuk bercocok tanaman dan membuat tempat pemukiman serta menjadi tempat mereka mencari hidup, tempat ini sekarang dinamakan Tanjung Medu atau Lebah Kuning.

Para leluhur desa Sako dahulunya membuat desa ini sebelum didiami diraja sesajen sepanjang 500 Meter, yaitu untuk menangkal dari serangan binatang buas dan penjahat yang berniat jahat, setelah itu barulah membuat rumah dan tempat peribadatan. Pada saat itu nenek moyang Sako beradu ilmu dengan nenek moyang desa Sungai Dua dan sebelum bertanding nenek moyang berpesan kepada pengikutnya kalau suatu saat saya tercundang dan meninggal dunia tolong kalian jangan bersedih namun kalian siapkan pesta kemenangan dengan gendang tetawak diiringi dengan pencak silat dan hiasi aku. Dan sampailah pada hari untuk beradu ilmu kanuragan dan nenek moyang meninggal sesuai dengan pesan yang telah disampaikan maka dibuatkanlah pesta dengan tetabuan gendang tetawak diiringi dengan pencak silat (M. Jana, 2010:1).

\section{Stratigrafi Sejarah Desa Sako Struktur Geologi}

Gambaran geologi kabupaten Banyuasin menjabarkan jenis tanah serta penjelasan mengenai daerah rawan bencana yang ada di wilayah kabupaten Banyuasin. Pada gambaran geologi tidak hanya dijelaskan secara deskriptif tetapi juga didukung oleh peta jenis tanah, dan peta rawan bencana dengan skala peta 1:50.000. Sebaran kondisi geologi berdasarkan stratigrafi penyusunnya dalam kabupaten Banyuasin.

\section{Mata air}

Menurut Heri Setianto terdapat banyak mata air yang sebagian besar berada di daerah perbukitan ditandai dengan adanya jalur sungai-sungai kecil dan adanya sipage dan rembesan air dari sisi hidrologi berdasarkan sifat tata air, wilayah kabupaten Banyuasin dapat dibedakan menjadi daerah dataran kering dan daerah dataran basah yang sangat dipengaruhi oleh pola aliran sungai. Aliran sungai di daerah datarah basah pola alirannya rectangular dan di daerah dataran kering pola alirannya dendritik. Beberapa sungai besar seperti sungai Musi, sungai Banyuasin, sungai Calik, sungai Telang, sungai Upang dan yang lainnya berperan sebagai sarana transportasi air berupa alur pelayaran pedalaman yang dapat menghubungkan pusat kegiatan wilayah, pusat kegiatan lingkungan, antar pusat pelayanan lokal serta antar pusat pelayanan lingkungan. Pola aliran di wilayah ini, terutama di daerah rawa-rawa dan pasang surut umumnya rectangular, sedangkan untuk daerah yang dipengaruhi oleh pasang surut aliran sungainya adalah sub parali, dimana daerah bagian tengah disetiap daerah sering dijumpai genangan air yang cukup luas. Terkait kondisi hidrologi, kabupaten Banyuasin terbagi kedalam 5 wilayah daerah aliran sungai yang masingmasing Das Bangke meliputi kawasan Taman Nasional Sembilang, Das Banyuasin yang merupakan Das terbesar meliputi kecamatan Tungkal llir, Pulau Rimau, Suak Tapeh, Sembawa, Betung, Banyuasin III, Tanjung Lago dan bagian selatan Banyuasin II, Das Benawang meliputi sepanjang wilayah Timur kecamatan Muara Sugihan, Sumber Marga Telang dan Muara Padang, Das Sembilang yang meliputi bagian Utara kawasan Taman Nasional Sembilang dan Das Musi yang meliputi kecamatan Rambutan, Banyuasin I, Air Kumbang, Talang Kelapa, Makarti Jaya, Muara Telang, Air Salek, Tanjung Lago, Rantau Bayur serta sebagian wilayah di kecamatan Banyuasin II. Pembagian daerah aliran sungai di kabupaten Banyuasin 
diilustrasikan pada gambar berikut (Catatan observasi no 5, Tanggal 28 Mei 2016).

\section{Jenis Batuan}

Kabupaten Banyuasin digambarkan melalui stratigrafi penyusunnya yang terdiri dari aluvium, batu lempung, batu pasir, batu sabak, endapan rawa, filit dan granit.

1. Aluvium endapan danau dan pantai: tersebar di seluruh Kecamatan

2. Batu Lempung, Batu Lanau, Batu Pasir: tersebar di sebagian kecamatan Banyuasin Dua, Pulau Rimau, Tungkal llir, Betung, Banyuasin Tiga, Rantau Bayur dan Suak Tapeh.

3. Batu Pasir, batu lumpur dan batu bara: tersebar di sebagian kecamatan Pulau Rimau

4. Batu Sabak, Filit dan Batu Lumpur: tersebar di sebagian kecamatan Tanjung Lago

5. Endapan Rawa: tersebar di selatan bagian Timur kabupaten Banyuasin yaitu kecamatan Betung, Suak Tapeh, Banyuasin III, Talang Kelapa dan Rantau Bayur

6. Filit dan Batu pasir: tersebar di sebagian kecil wilayah perbatasan kecamatan Tanjung Lago dan kecamatan Pulau Rimau.

7. Granir, Granodiorit, Diorit: tersebar di sebagian kecamatan Pulau Rimau, Banyuasin II, Tanjung Lago dan Rambutan.

Dari jenis stratigrafi tersebut yang paling mendominasi adalah jenis aluvium yang terbentuk dari endapan danau dan pantai. Selanjutnya adalah jenis endapan rawa yang tersebar di selatan bagian timur kabupaten Banyuasin yaitu kecamatan Betung, Suak Tapeh, Banyuasin III, Talang Kelapa dan Rantau Bayur dan persebaran paling sedikit yaitu jenis filit yang hanya terdapat di sebagian kecil wilayah perbatasan kecamatan Tanjung Lago dan kecamatan Pulau Rimau (Bps. Kab Banyuasin 2014).

\section{Daerah Pertambangan}

Sebagian besar wilayah kabupaten Banyuasin adalah dataran rendah, daerah ini memiliki potensi yang besar dalam bidang pertambangan. Pertambangan yang banyak terdapat di Banyuasin adalah pertambangan mineral terutama kandungan minyak bumi dan gas. Daerah ini tersebar dari sebelah Barat wilayah Banyuasin yaitu yang berbatasan dengan wilayah kabupaten Musi Banyuasin hingga wilayah Timur yang berbatasan dengan Kabupaten Ogan Komering llir. Wilayah pertambangan minyak dan gas yang saat ini diolah oleh pemerintah terletak di Sungai Gerong kecamatan Banyuasin I. Bahan tambang berupa minyak dan gas bumi yang ada di Banyuasin, berasal dari sisa-sisa endapan makhluk hidup yang telah terkubur ribuan tahun yang lalu. Banyaknya potensi tambang di daerah Banyuasin menjadikan Banyuasin sebagai salah satu lumbung energi nasional (Bps. Kab Banyuasin 2014).

Menurut Heri Setianto dari hasil pengamatan dilapangan desa sako kecamatan Rambutan kabupaten Banyuasin memiliki potensi pertambangan minyak bumi dan gas. Hal ini dapat dibuktikan dengan banyaknya lapisan mineral yang berasal dari hewan laut pada kedalaman \pm 7 meter dari permukaan tanah (Catatan wawancara no 5).

\section{Stratigrafi Desa Sako}

Stratigrafi pantai kuno pada desa Sako terbentuk dalam waktu yang cukup lama yaitu diperkirakan ribuan tahun yang lalu. Hal ini dapat dilihat dari lapisan-lapisan tanah yang menutupi lapisan pasir dan binatang-binatang laut yang baru ditemukan pada kedalaman \pm 20 meter dari lapisan tanah yang paling atas. Selain endapan pasir dan fosil kerang dilokasi kedukan juga ditemukan tumpukan-tumpukan batu yang diduga adalah batu karang yang telah tertimbun ribuan tahun yang lalu. Lokasi kedukan tersebut saat ini berada $\pm 1 \mathrm{Km}$ dari tepi sungai Musi. Wilayah desa Sako 
diperkirakan dulunya adalah tepian laut yang mengalami pendangkalan sehingga membentuk daratan. Hal ini diperkirakan karena adanya banjir bandang yang membawa berbagai material tanah dan lumpur yang menimbun tepian laut sehingga membentuk daratan.

\section{Warna Lapisan}

a. Tanah permukaan: Lapisan tanah mineral dengan akumulasi bahan organik dan soil 2. life. Lapisan mengeluviasikan iron, aluminium, senyawa organik, dan komponen terlarut lain nya.

b. Subsoli: Lapisan ini mengakumulasikan besi, aluminium dan senyawa organik

c. Batuan/ bahan induk: Lapisan batuan berukuran besar yang belum hancur lapisa ini mengakumulasikan senyawasenyawa yang dapat larut (Bps. Kab Banyuasin 2014).

\section{Jenis Lapisan}

Jenis lapisan yang terdapat di daerah desa Sako memiliki jenis-jenis sebagai berkut:

\section{A : pucat}

A2 : pucat terang

B1 : kuning kecoklatan

C : coklat gelap (BPS. Kabupaten

Banyuasin 2014).

Jenis lapisan tanah diketahui dari proses pendataan di lapangan dimana peneliti mengambil sampel tanah dan mencocokannya dengan buku pedoman tanah yang dipergunakan pada waktu penelitian.

\section{Kandungan Lapisan Sejarah dan Temuan Desa Sako}

Berdasarkan hasil penggalian yang telah penulis lakuan bersama tim peneliti sejarah universitas PGRI Palembang, didapatkan hasil bahwa lapisan-lapisan tanah yang ada di desa Sako Kecamatan Rambutan memiliki tekstur dan warna yang berbeda-beda pada setiap lapisan tanahnya. Lapisan-lapisan tanah yang ada memiliki kandungan-kandungan endapan yang sangat beragam. Pada lapisan tanah atas tanah mengandung humus dan organisme-organisme kecil seperti cacing dan serangga. Pada lapisan tanah kedua yang berwarna merah keputih-putihan mengandung sedikit lempung dengan tekstur yang agak liat. Lapisan tanah berikutnya berwarna agak kekunigan dengan kandungan kerikil dan sedikit lempung dengan tekstur liat. Dan pada lapisan tanah terakhir (kedalaman > 20 meter) kandungan tanahnya agak berpasir dengan warna kehitam-hitaman dengan kandungan fosil-fosil kerang dan batu-batu karang dan memiliki tekstur yang lembut seperti butiran-butiran pasir yang halus (Catatan penelitian 2016).

Lapisan tanah terakhir diperkirakan dulunya adalah daerah pantai atau tepian laut yang terpendam lebih dari ribuan tahun. Hal ini dikarenakan letaknya yang telah mencapai kedalaman lebih dari 20 meter dari lapisan tanah yang paling atas. Lapisan tersebut mengandung berbagai unsur yang mirip dengan kondisi daerah pantai atau perairan laut sehingga kemungkinan besar dulunya lokasi penggalian tersebut adalah pantai atau daerah tepian laut yang telah tertimbun selama ribuan tahun (Observasi penggalian tanggal 24 Januari 2016).

Selain situs pantai kuno yang terdapat di desa Sako kecamatan Rambutan, ditemukan juga sebuah situs sejarah yang diduga merupakan peninggalan kerajaan Sriwijaya tidak jauh dari lokasi kedukan stratigrafi pantai kuno. Situs sejarah yang ditemukan berupa tumpukan bata yang membentuk seperti susunan pondasi sebuah bangunan. Situs tersebut memiliki panjang 18,5 m. Batu bata yang ditemukan dilokasi penggalian memiliki bentuk dan ukuran yang berbeda dengan bentuk dan ukuran bata saat ini. Bata yang ditemukan memiliki panjang $\pm 25 \mathrm{~cm}$ lebar $\pm 15 \mathrm{~cm}$ dengan ketebalan $\pm 5 \mathrm{~cm}$ dan memiliki lekukan pada tengah bata. Selain itu 
menurut beberapa sumber, lokasi ditemukannya tumpukan bata tersebut adalah daerah perkebunan karet rakyat yang letaknya jauh dari pemukiman penduduk, jadi kecil kemungkinan bahwa situs yang ditemukan adalah bekas bangunan baru. Batu bata yang ditemukan juga bukan merupakan hasil produksi dari pembuat baru bata yang ada di desa Sako. Berikut ini adalah beberapa gambar yang berhasil didokumentasikan (Observasi penggalian tanggal 24 Januari 2016).

\section{Pembahasan}

Dalam pembelajaran sejarah kelas VII SMP Karya Sembawa bahwa stratigrafi di desa Sako termasuk pada Standar Kompetensi (SK), Kompetensi Inti (KI) dan Kompetensi Dasar (KD) sebagai berikut:

Standar Kompetensi: Memahami lingkungan kehidupan manusia

Kompetensi Inti:3. Memahami pengetahuan (faktual, konseptual, dan procedural) berdasarkan rasa ingin tahunya tentang ilmu pengetahuan, teknologi, seni, budaya terkait fenomena dan kejadian tampak mata.

Kompetensi Dasar: 1.1 Mendiskripsikan keragaman bentuk muka bumi, proses pembentukan dan dampaknya terhadap kehidupan.

Stratigrafi pantai kuno desa Sako kecamatan Rambutan merupakan sumber pembelajaran sejarah dikarenakan proses terbentuknya dan merupakan peristiwa alam yang dapat dijadikan sebagai sumber informasi bagi masyarakat terutama siswa sekolah menengah pertama. Dilihat dari proses terbentuknya, stratigrafi merupakan proses endapan yang terjadi ribuan tahun. Siswa dapat mempelajari proses terbentuknya stratigrafi tersebut sebagai bahan untuk meningkatkan pemahaman dan ilmu pengetahuan tentang keragaman bentuk muka bumi dan proses pembentukannya serta dampaknya terhadap kehidupan sesuai dengan kompetensi dasar yang telah ditetapkan dalam sistem pendidikan nasional.
Penelitian ini menggunakan analisis SWOT, analisis Swot untuk mengetahui unsur Strength (kekuatan), Weakness (kelemahan), Opportunity (kesepakatan) dan Threath (ancaman) terhadap stratigrafi pantai kuno sebagai sumber pembelajaran sejarah siswa kelas VII SMP Karya Sembawa kecamatan Sembawa kabupaten Banyuasin.

Pembelajaran sejarah hendaknya mampu memanfaatkan potensi sejarah lokal daerah, terutama sejarah lokal yang dekat dengan sekolah dan siswa. Strategi pemanfaatan sejarah lokal ini diharapkan mampu menumbuhkan rasa empati di kalangan siswa pada sejarah daerahnya masing-masing.

Pemanfaatan potensi lokal dengan bekerjasama dengan stakeholder diharapkan mampu meningkatkan kualitas pembelajaran dan kerjasama terutama dengan lembaga/institusi pendidikan yang mengadakan penelitian sejarah seperti Universitas PGRI Palembang. Hasil penelitian dosen dan mahasiswa Program Studi Pendidikan Sejarah FKIP diharapkan dimanfaatkan secara optimal oleh pengguna.

Dukungan instansi terkait seperti Balai Arkeologi Sumatera Selatan dan Dinas Pendidikan Nasional akan semakim menguatkan kerjasama dan pelestarian sejarah lokal. Penulisan sejarah lokal sebagai asset lokal yang perlu dijaga dan dilestarikan dengan cara pengajaran pada peserta didikan di sekolah.

Kabupaten Banyuasin sangat kaya dengan data kesejarahan dan baru sebagian kecil saja yang terangkat kepermukaan melalui tulisan yang terpublikasi di surat kabar dan buku sejarah. penyebaran informasi kesejarahan terkini melalui hasil penelitian terkini di kegiatan pembelajaran di sekolah dan universitas diharapkan mampu mendorong minat penelitian dan mempublikasian data dan informasi kesejarahan hasil temuan dan 
penelitian ilmuwan di berbagai universitas di Sumatera Selatan.

Pembelajaran yang cocok dikembangkan oleh guru adalah dengan mengajak siswa langsung ke lapangan untuk mengamati fenomena-fenomea sejarah yang terjadi di lapangan sehingga siswa mampu mendeskripsikan data kesejarahan dengan baik dan tepat. Teknologi dan media yang cocok juga sebaiknya menyertai proses atau kegiatan pembelajaran di lapangan.

\section{SIMPULAN}

Dari hasil penelitian dapat disimpulkan:

1. Stratigrafi di desa Sako menggambarkan proses sejarah geologi Sumatera Selatan selama ribuan tahun. Proses geologi dari masa pra sejarah menggambarkan proses geologi pengangkatan dan proses endapan selama ribuan tahun.

2. Stratigrafi desa Sako menggambarkan nilai sejarah masa prasejarah berupa temuan sisa-sisa kehidupan mahluk laut pra sejarah, masa klasik HinduBudha berupa keramik Cina dan stuktur bata kuno pada lahan perkebunan milik penduduk. Sisa masa kesultanan berupa keramik cina, dan Eropa yang sezaman dengan masa kesultanan Palembang Darussalam. Masa kolonial Belanda ditandai dengan temuan keramik masa penjajahan Belanda berupa keramik Eropa. Masa penjajahan Jepang ditandai dengan temuan berbagai keramik Jepang, sisa barak militer Jepang dan lapangan terbang perintis yang dibuat Jepang yang letaknya tidak jauh dari desa Sako.

3. Stratigrafi desa Sako dapat dijadikan jadikan sumber pembelajaran sejarah Di SMP pada KI-3: Memahami pengetahuan (faktual, konseptual, dan procedural) berdasarkan rasa ingin tahunya tentang ilmu pengetahuan, teknologi, seni, budaya terkait fenomena dan kejadian tampak mata. Kompetensi Dasar 1.1 Mendiskripsikan keragaman bentuk muka bumi, proses pembentukan daan dampak nya terhadap kehidupan.

\section{DAFTAR PUSTAKA}

Abdul Rahman Panji Kemas. 2008. Pengantar Ilmu Sejarah. Palembang: IAIN Raden Fatah Palembang.

Arikunto, Suharsimi. 2013. Prosedur Penelitian. Jakarta: Rineka Cipta.

Bps. Banyuasin dalam angka 2014

Budiningsih C Asri, DR. 2012. Belajar dan Pembelajaran. Jakarta; Rineka Cipta.

Dahlan Balfas Muhammad. 2015. Geologi untuk Pertambangan dan Umum. Yogyakarta; Graha IImu.

Dimyati Dr, Drs. Mudjiono. 2013. Belajar dan Pembelajaran. Jakarta; Departemen Pendidikan dan Kebudayaan dan Rineka Cipta.

FKIP. 2015. Pedoman Penulisan Skripsi.

Palembang; Universitas PGRI Palembang.

Hasan Muhammad Tholchah Dkk. 2009. Metode Penelitian Kualitatif, Tinjauan Teoritis dan Praktis. Surabaya: Visipress Media.

Jembar TIM, 2007. Ensiklopedi Bergambar (2) Sejarah Bumi. Bandung; Jembar.

M. Jaya Sugiharto. 2010. Sejarah Desa dan Masa Pemerintahan Desa Sako. Palembang:Unpliblised.

Ngadiyo. 2010. Pedoman Umum Ejaan Bahasa Indonesia yang Disempurnakan. Bandung: Yrama Widya.

Oliver, 2004. Guide To Seashells. London; Philip's

Priyadi Sugeng. 2012. Sejarah Lokal Konsep, Metode, dan Tantangannya. Yogyakarya;Ombak.

Puspitaningasih, 2012. Mengenal Ekosistem Laut dan Pesisir. Jakarta; Pustaka Sains.

Sukendar Haris, 2000. Metode Penelitian Arkeologi. Jakarta: Departemen 
Pendidikan Nasional dan Pusat Penelitian Arkeologi Nasional.

Sutopo, 2006. Metodologi Penelitian Kualitatif Dasar Teori dan Terapannya Dalam Penelitian. Surakarta; Universitas Sebelas Maret.

Widiyanto Andri. 2008. Memahami Sains dari Alam, Laut dan Pantai. Bandung; Mitra Utama.
Yanuarti Eka, 2013. Metodologi Penelitian Pendidikan. Palembang; Universitas PGRI Palembang Sumatera Selatan

http://www.artikelsiana.com/2015/04/ pengertian-variabel-macam-macamvariabel-para-ahli.html\# akses 5:08 PM. 29 Februari 2016. 